\title{
Measurement of Noise from Road Surface Using Dynamic Method
}

\author{
V. Křivánek* \\ Transport Research Centre, Brno, Czech Republic, \\ * Corresponding author: vitezslav.krivanek@cdv.cz
}

DOI: $10.2478 / \mathrm{v} 10158-012-0038-8$

\begin{abstract}
Road transport has been the dominant source of noise in the environment for many years and most of the noise is nowadays generated by the interaction of the tyre with the road, beginning with relatively low speeds. The condition of the road wearing course is the factor that particularly influences the noise pollution generated by the movement of vehicles on roads. The CPX method (CloseProXimity) used for measuring the amount of noise from the rolling of tyres consists of drawing a special trailer fitted with reference test tyres that are surrounded by microphones recording the noise generated by the rolling tyres along a test section. This dynamic method allows the evaluation the noise from the road surface in the field for the full length of the examined road section. It can be performed during the normal operation of the road with no need for traffic restrictions. Monitoring and early exchange of road surface can significantly contribute to the sustainable development of transport and a reduction of its negative impacts on the environment and human health thanks to the effective reduction of the excessive noise from road traffic. This paper presents the process of field measuring tests with a subsequent evaluation of results.
\end{abstract}

KEY WORDS: CPX method, road-noise measurement, tyre/pavement, road-noise reduction.

\section{CPX METHOD}

The CPX method is described in detail in the draft standard ISO/CD 11819-2 - Acoustics Method for measuring the influence of road surfaces on traffic noise - Part 2: The Close Proximity method, 2000. Measurements are performed with the intention to determine the noise produced at the tyre/road interface at one or more reference speeds $-40,50,80$, and $100 \mathrm{~km} / \mathrm{h}$. The method gives a good estimate of the acoustic characteristics of road surfaces. It can be used to study the homogeneity of road surfaces over long distances and under different conditions, or monitor the road maintenance so as to assure its efficiency (Ongel et al., 2008; Paje et al., 2010). The advantage of assessing the tyre performance using this method is that the influence of other sources of noise, such as the engine noise and the noise from exhausts, is reduced to a minimum (Wong et al., 2009).

\subsection{Equipment for measurement using CPX}

For the actual measurement, the Tigerpaw Uniroyal 225/60 R16 SRTT tyre is used all over the world as the reference tyre. Five measuring microphones connected to a suitable noise analyzer are placed at a height of $0.1 \mathrm{~m}$ and $0.2 \mathrm{~m}$ above the road surface at a distance of $0.2 \mathrm{~m}$ and $0.65 \mathrm{~m}$ from the tyre/road surface interface, exactly according to the relevant standard (ISO/CD 11819-2), see Figure 1. For the measurement, a specially designed trailer 
pulled behind a car is used (Křivánek \& Cholava, 2010; Křivánek et al., 2012) see Figure 2. This equipment needs to meet strict requirements, which are described in detail in the draft standard ISO/CD 11819-2 (e.g. the measurement must not be influenced by other vehicle parts, permanent position of microphones, absence of reflecting surfaces, dimensions, load, etc.).

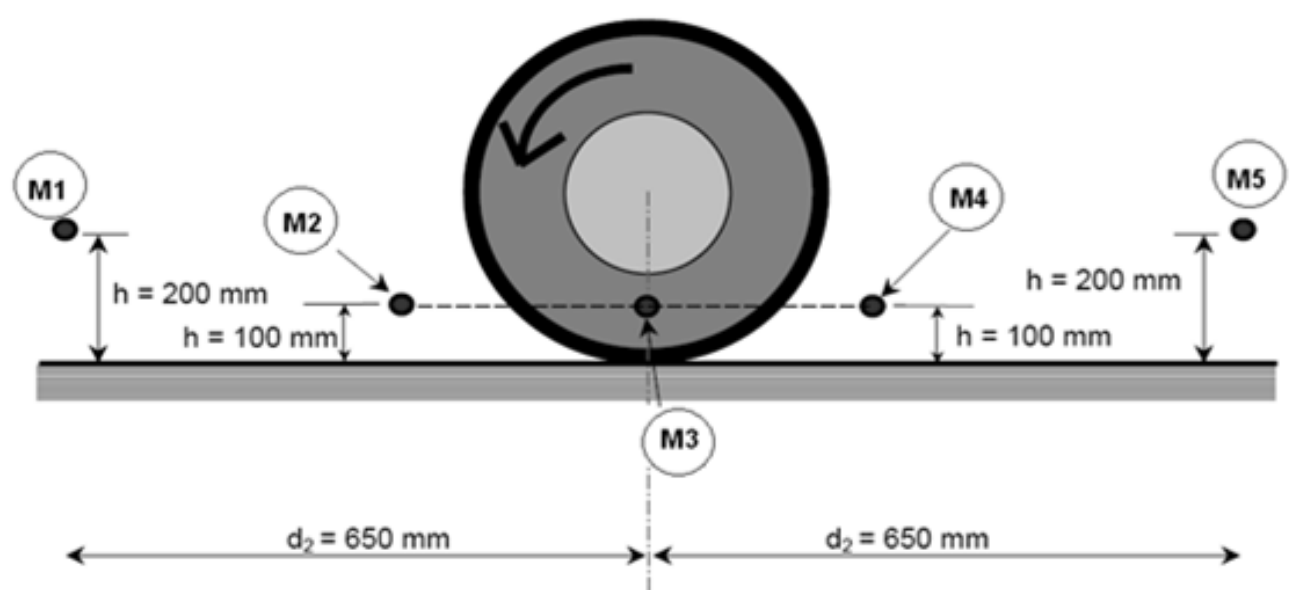

Figure 1: Location of individual measurement microphones on CPX trailer.

The measurement using the CPX method does not depend on the density of the surrounding traffic flow. However, it is very helpful if the traffic flow density at the time of measurement is as low as possible, allowing a constant speed to be easily maintained on the measured road section. Measurements can be performed only on completely dry roads, due both to the requirements of the relevant standard and economic reasons, as in the case of a wet road surface the very sensitive measuring microphones fitted only at the minimum height from the road surface $(0.1$ and $0.2 \mathrm{~m})$ could be damaged or destroyed. There is therefore a limited number of suitable terms when this measurement can be performed - it must not rain at least two days prior to the measurement at the locality in question (the road is dry), wind speed does not exceed $5 \mathrm{~m} / \mathrm{s}$ and the air temperature is higher than $5^{\circ} \mathrm{C}$.

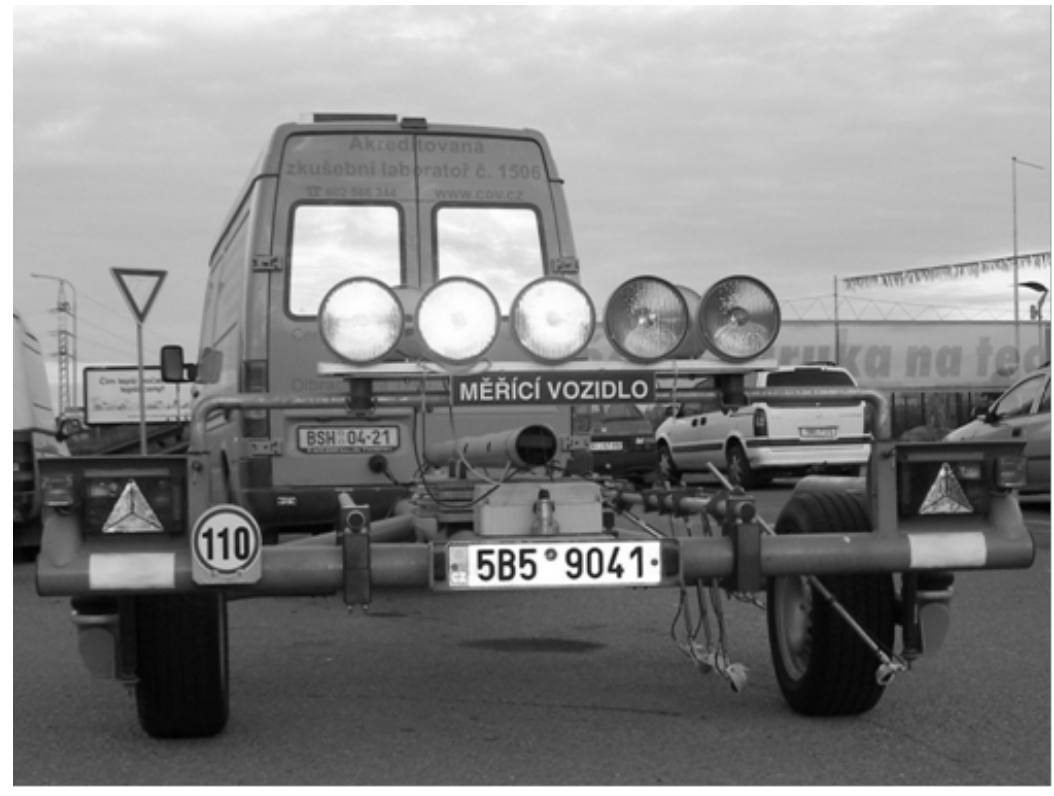

Figure 2: Placement of individual measurement microphones on CPX trailer. 
As according to the last CPX draft standards it is very important to monitor the speed and the ambient temperature (Anfonsoo \& Pichaud, 2007; Krrivánek et al., 2012) to implement the speed and temperature corrections to the relevant reference values. We use devices shown in Figure 3 that are connected to the measuring laptop. The measured data (noise at the tyre/road surface interface, air temperature, speed of the measurement system, and its position) are fully synchronized, allowing the measured places to be accurately located together with the specific velocity of the measuring system at a particular place, and the surface temperature, which is important for possible correction of the measured values to a constant reference velocity $(40,50,80$, or $100 \mathrm{~km} / \mathrm{h})$ and the reference temperature $\left(20^{\circ} \mathrm{C}\right)$. During the actual measurement it is suitable to use the cruise control in the vehicle, so as to keep the speed during the measurement as constant as possible and as close to one of the reference velocities as possible.
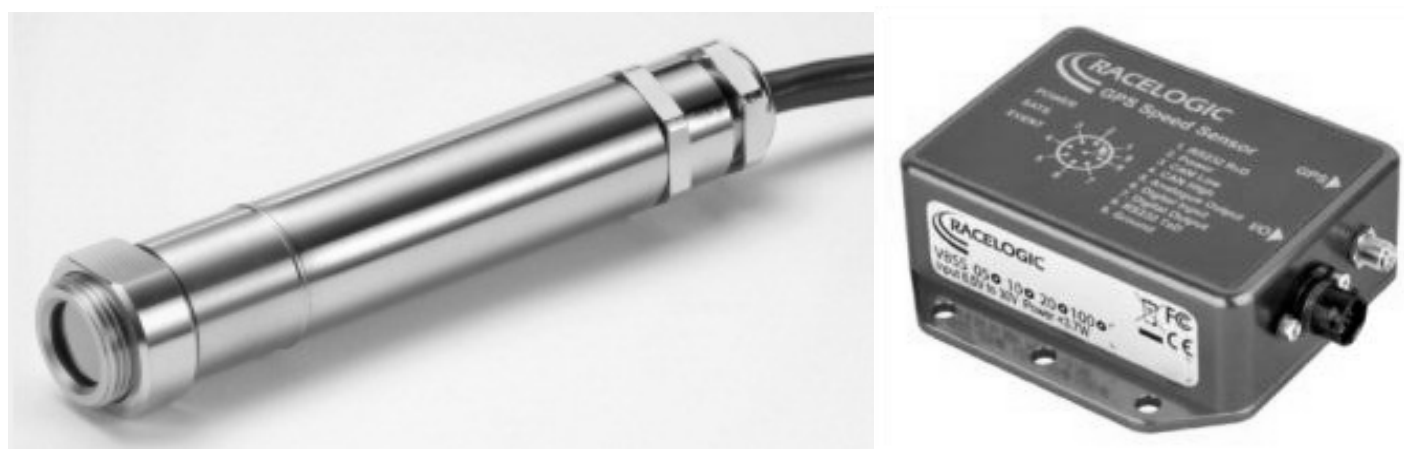

Figure 3: Non-contact infra-red temperature sensor CALEX and GPS module.

\section{PROCESS OF MEASUREMENT WITH CPX METHOD}

At an appropriate place - most often a parking place - before the measured section a final preparation phase for the actual measurement is accomplished, when individual microphones are set up in their particular positions desired for the measurement. Particular fastening clamps and the tightening nut for the fastening of microphones are then tightened so as to prevent the change of their position during the measurement. Cables are connected to individual microphones and at several places attached with the use of mounting strips. Microphones are fitted with protective caps that are also firmly attached by pieces of elastic bandages, which hold the protective caps of microphones in place during the measurement without compromising the recorded acoustic situation.

After making the final adjustments the vehicle can move towards the section to be measured. The measurement recording devices are switched on prior to reaching the measured section as the measuring van reaches the desired measuring speed and cruise control is put in action. The measured road is driven in regular traffic conditions. Microphones are unidirectional and are placed at a very small distance from the measured tyre that emits a loud noise which is recorded. For this reason the influence of the surrounding traffic on the acoustic situation recorded by microphones (the sources of which are at least at ten times a greater distance) are negligible - the distance from individual other sources of noise is large enough (Cho \& Mun, 2008).

As the vehicle attains the desired speed and enters the measured section, the operator starts the measurement by switching on all five microphones. If the beginning of the analyzed road section or reaching the desired speed is different from the start of the measurement, the operator makes a verbal mark with an additional microphone or inserts a "mark" into the measurement record. This allows measuring also on consecutive sections of roads. 
There are two basic options for the recording of the measurements: storing a raw signal or storing analyzed variables (one-third-octave characteristics, course of the level, etc.). Since these measurements have an influence on the human organism, all measurements are adjusted with an A-weighting filter. In accordance with standards IEC 61260 and ISO/CD 11819-2, the measurement or analysis is performed in the one-third octave frequency range from $315 \mathrm{~Hz}$ to $5 \mathrm{kHz}$ (Cho \& Mun, 2008). By averaging all measured values from all measuring microphones we get the corresponding value of the equivalent level of acoustic pressure, and one-third-octave characteristics of the acoustic pressure when using an A-filter for the given segment of the measured road surface.

\subsection{Example of evaluation of the measurement record}

Storing the raw signal from the measurement has the advantage of having the possibility to process the results at ease at any time after the measurement and, moreover, it is possible to change the parameters of the raw signal that we want to analyze. A partial selection of one segment of the raw signal from the stored record is shown in Figure 4, where the bottom part of the figure shows a closer detail of the analyzed section that was selected for analysis.

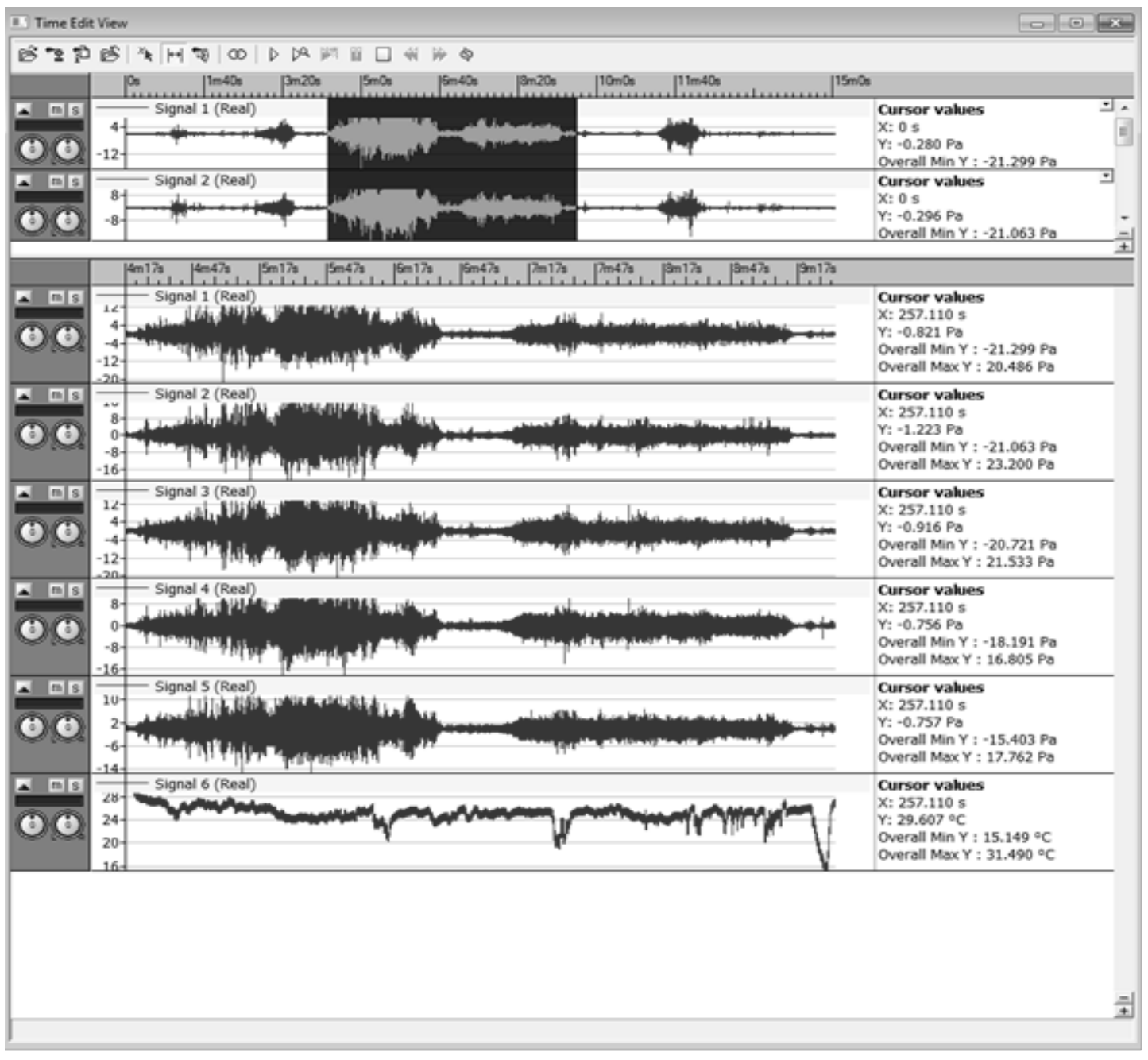

Figure 4: Saved record of the raw signal for 5 measurement channels and a temperature sensor, with a cut selected for analysis. 
In the relevant software environment for the analysis of the measurements (in our case, the software Pulse 16.1) it is necessary to define what kind of parameters should be evaluated. Concerning the noise at the tyre/road surface interface we are particularly interested in the dependence of noise on time (first part of Figure 5), which allows the noise generated from road surfaces in the field to be evaluated in their full length. Figure 5 illustrates the measurement on two consecutive road sections of approximately equal length (on the relative time axis it corresponds to about $40-120 \mathrm{~s}$ and $200-280 \mathrm{~s}$ of the record of the selected partial segment of raw signal) at a speed of $50 \mathrm{~km} / \mathrm{h}$ (middle of the figure) and a temperature of about 23 to $26^{\circ} \mathrm{C}$ (the third, lowest part in Figure 5). For an ordinary comparison, to find places in which the road surface is noisier, it is not necessary to make temperature corrections since the reference velocity of $50 \mathrm{~km} / \mathrm{h}$ was maintained for the whole length of the measured sections, and there is a low variability of the surface temperature at the given places, but if the results will be used for comparing the noise emitted from different types of surfaces with different characteristics and from different places, it may be necessary to make corrections of the upper part of Figure 5 for temperature variations from the bottom part of the same figure so that the equivalent level of noise corresponds to the reference temperature of $20^{\circ} \mathrm{C}$.
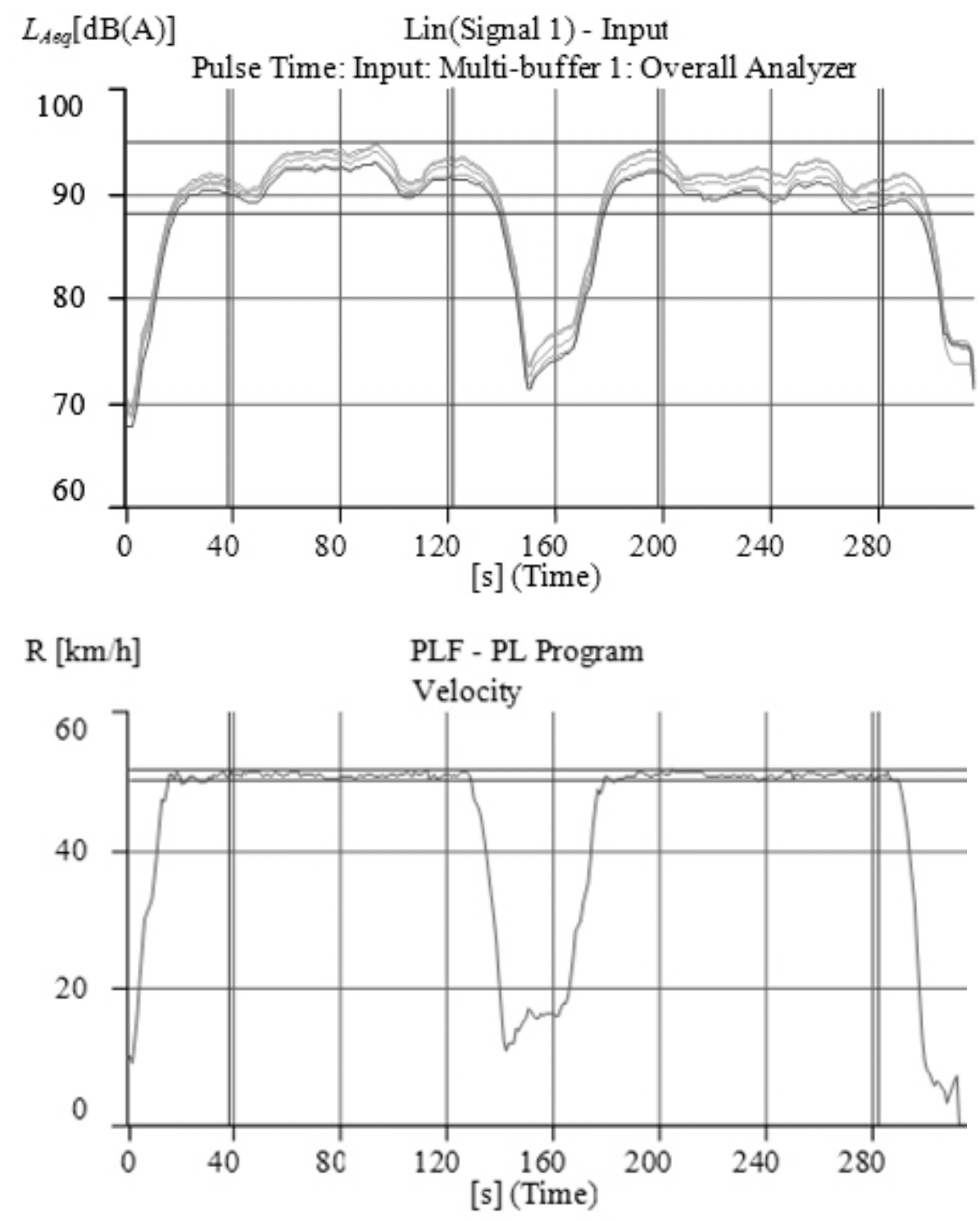


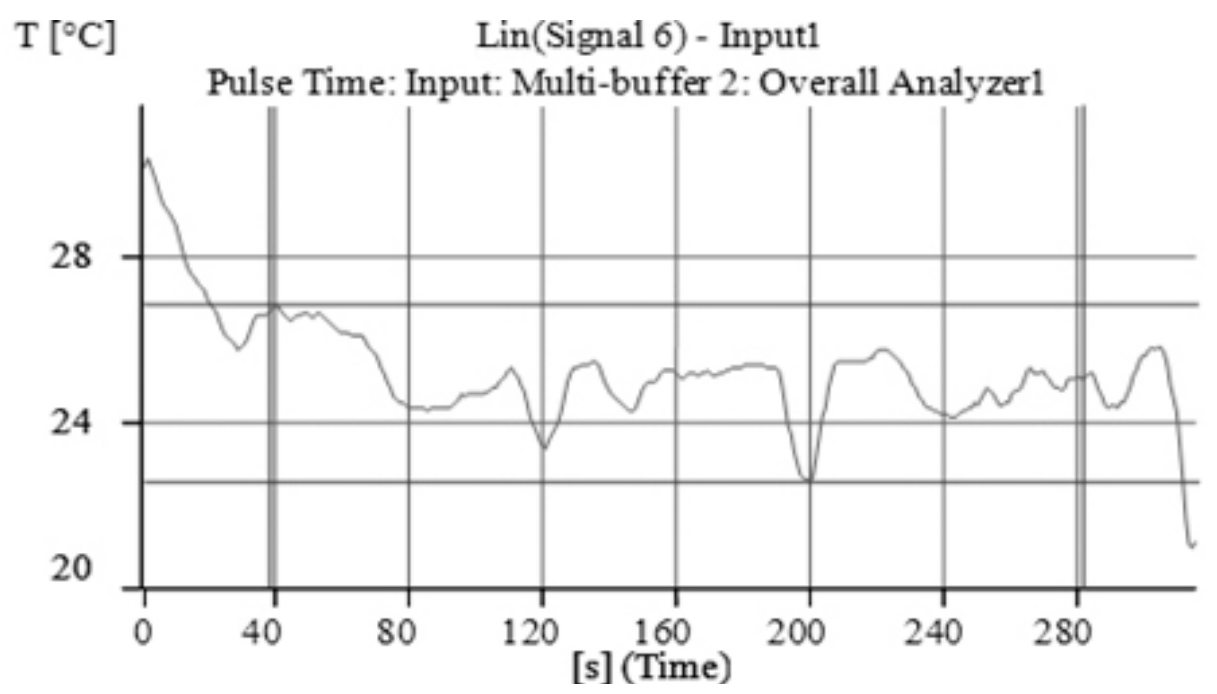

Figure 5: Equivalent noise levels, speed and temperature on a selected section on synchronized timeline.

\section{CONCLUSION}

This paper discusses the dynamic method where the measurement consists of the assessment of noise emitted from the whole length of road on the basis of special reference tyres by CPX method. CDV within the projects "Change of noise from road surfaces over several years of use" (Křivánek et al., 2012) and "Transportation R\&D Centre" further innovated, improved and optimized the trailer they designed for measurement with the CPX method the only device in the $\mathrm{CZ}$ for noise measurement using the CPX method. The paper describes the basic measuring equipment used that also allows the fitting of additional devices for the synchronous measuring of other important parameters.

The CPX method gives a good estimation of the acoustic properties of road surfaces. Traffic noise is currently one of the most discussed topics; it affects a large number of people, and thus there are efforts to reduce noise in the vicinity of roads. The construction of road wearing courses and road surfaces with reduced noise emissions allow for noise reductions right at the interface of a tyre with the road surface (Dürr et al., 2011; Plitz \& Švadlák, 2011; Sýkora et al., 2010; Valentin \& Mondschein, 2010) which can be clearly assessed through the use of the CPX method. Furthermore, it can be used to study the homogeneity of road surfaces over long distances and under different conditions, or to monitor maintenance and assess its effectiveness (Kašpar \& Bureš, 2011; Kudrna et al., 2011; Stoklásek, 2010) noise testing and confrontation with the requirements specified in tender documents, monitoring of the acoustic behaviour of the road over several years of use.

\section{ACKNOWLEDGEMENTS}

The research described in this article was established within the research project of the Technology Agency of the Czech Republic TA01030459 "Change of noise from road surfaces over several years of use". 


\section{REFERENCES}

Anfonsoo, L., F., Pichaud, Y., 2007. Temperature effect on tyre-road noise. Applied Acoustics, 68 (1), pp. 1 - 16. ISSN 0003-682X.

Cho, D., S., Mun, S., 2008. Study to analyze the effects of vehicles and pavement surface types on noise. Applied Acoustics, 69 (9), pp. 833 - 843. ISSN 0003-682X.

Dürr, J., Zrzavý, J., Trešl, O., 2011. Snížení hluku z povrchu při použití speciální asfaltové směsi pro obrusnou vrstvu vozovek. Silniční obzor, 72 (10), pp. 272-277. ISSN $0322-$ 7154. (in Czech)

FEHRL, 2008. Report on state-of-the-art of test methods, Seventh Framework Programme, FP7-217920. Netherlands: FEHRL.

ISO/CD 11819-2, 2000. Acoustics - Measurement of the influence of road surfaces on traffic noise - Part 2: The close-proximity method.

Kašpar, R., Bureš, P., 2011. VIAPHONE - Tenká obrusná vrstva s nízkou hlučností. In Asfaltové vozovky 2011. Praha: Pragoprojekt, a.s. ISBN 978-80-903925-2-6. (in Czech)

Křivánek, V. et al., 2012. Změna hluku povrchů vozovek v průběhu několika let používání: Průběžná zpráva. [Change of noise from road surfaces over several years of use: Progress report]. Brno: Transport Research Centre (CDV). 109 s. Submitter: Technology Agency of Czech Republic. (in Czech)

Křivánek, V., Cholava, R., 2010. Static and Dynamic Method for the Measurement of the Noisiness of Road Surfaces. In IV. Czech-Slovak Scientific Conference, Transport, Health and Environment, Blansko (Czech Republic), November 2-3, 2010. Brno: Transport Research Centre, pp. 231-263. ISBN 978-80-7399-141-8.

Kudrna, J. et al., 2011. Asfaltové směsi snižující hlukové emise a zlepšující protismykové vlastnosti. In Asfaltové vozovky 2011. Praha: Pragoprojekt, a.s. ISBN 978-80-903925-2-6. (in Czech)

Ongel, A. et al., 2008. Comparison of surface characteristics and pavement/tire noise of various thin asphalt overlays. Road Materials and Pavement Design, 9 (2), pp. 333 344. ISSN 1468-0629.

Paje, S., E. et al., 2010. Monitoring road surfaces by close proximity noise of the tyre/road interaction. Journal of the Acoustical Society of America, 122 (5), pp. 2636 - 2641. ISSN 0001-4966.

Plitz, J., Švadlák, D., 2011. Nové druhy monoasfaltu pro obrusné vrstvy se sníženou hlučností. In Asfaltové vozovky 2011. Praha: Pragoprojekt, a.s. ISBN 978-80-903925-2-6. (in Czech)

Stoklásek, S., 2010. Akusticky optimalizované povrchy vozovek nedrenážního typu. Zpravodaj SILNICE MOSTY, (3). (in Czech)

Sýkora, M. et al., 2010. Asfaltové vrstvy s nízkou hlučností u firmy EUROVIA. Zpravodaj SILNICE MOSTY, (4). (in Czech) 
Valentin, J., Mondschein, P., 2010. Snižování hluku možnými úpravami obrusné vrstvy vozovky. Silnice, Železnice, (5). ISSN 1803-8441. (in Czech)

Wong, K. W. et al., 2009. A new methodology of measuring tyre/joint noise in Hong Kong. In 4th International Symposium on Environment Vibrations - Prediction, Monitoring, Mitigation and Evaluation, pp. 599 - 604. ISBN 978-7-03-025765-9.

The article was produced under the support of the project

Transport R\&D Centre (CZ.1.05/2.1.00/03.0064) 